\title{
Respect for Human Beings and Education as a Possibility of Overcoming the Situation of Injustice
}

\author{
Ogun Urek \\ Uludag University
}

\begin{abstract}
Kuçuradi (1994), in a paper entitled "The concept of Justice," makes a determination in terms of the situation of injustice by comparing individual situations. In her opinion, when we consider the injustice in individual situations, we consider two different things and compare them through a third (middle) term. In other words, we consider: (1) some things that a person possesses at a certain moment, (2) the things that another person possesses at a certain moment, and (3) we compare human beings as a species, in respect of the actualisation of the human potentialities at this historical moment. From the Kuçuradi's point of view, conceptualization of the idea of justice, that is, giving an answer that can be established by knowledge to the question of "what is justice?" is the inevitable condition for surpassing this situation (1994). But, here we may claim that the situation of injustice can be surpassed by the feeling of respect for human being in the Kantian sense without the conceptualizing the idea of justice as a precondition. If certain persons who actualize the human potentialities in a higher degree than others at the same historical moment and act with a will determined by the law of moral, shall inevitably be respected by other persons who have not yet actualized such potentialities in themselves. It seems that the appearance of this feeling is possible only through a moral education in the Kantian sense, through which persons who have actualized human potentialities in a higher degree will possess a will determined by the moral law.
\end{abstract}

Keywords: respect, sense, justice, injustice, freedom

\section{Kuçuradi's Concept of Justice}

Kuçuradi makes a significant and extremely striking determination with regard to human condition in today's world in her paper entitled "The concept of Justice." According to the determination, "by the increased population of the world, the number of those who do not aspire to but want justice increases and in their despair of 'having' it, they take up arms by which they annihilate people at random and themselves as well" (Kuçuradi 1994, 27). Small wars and terrorism in today's world are the result of this. At this point for solving this problem, Kuçuradi tries to give an answer to the question of "what is justice?" which can be cognitively justifiable (Kuçuradi 1994, 27).

According to Kuçuradi, among the various attempts to answer the question of "what is justice?" There is something we can learn from Plato in this respect. That is, justice is not a real thing but an idea. According to the Platonic conception of idea, for ideas in the intelligible world, there must be an actual base which corresponds to it in the visible world. This actual base shows us the place at which we should look in an attempt

Ogun Urek, Associated Professor, Department of Philosophy, Uludag University, Turkey; main research fields: Ethics, Philosophy of Value, and Philosophy of Law. Email: ogunurek@uludag.edu.tr. 
to find a cognitively justifiable answer to the question of "what is justice as an idea?" From the point of view of Kuçuradi, "this is injustice, which is a state of affairs, a fact, and not an idea as justice is. Injustice is the place where we find the ò $\phi \varepsilon \imath \lambda$ ó $\mu \varepsilon v \alpha$ (this ancient Greek word means "Due" in English) to human beings as such; or if we wish to call these ò $\phi \varepsilon \imath \lambda$ ó $\mu \varepsilon v \alpha$ by their modern name, it is the source wherefrom we deduce the principles we call basic human rights" (Kuçuradi 2007, 441). For her, therefore, "this means that we have to change our initial question in order to become able to answer it, and to ask first what injustice is" (Kuçuradi 2007, 441).

Kuçuradi defines injustice: "thus, injustice, in general, would denote: the state of affairs in which the existing conditions are unfavourable, or hinder individuals or groups from exercising their human rights-conditions created directly or indirectly, by other individuals or groups, either at the national or international levels" (Kuçuradi 2007, 442). According to Kuçuradi, a comparison is drawn at this point. In this comparison, we compare the conditions of some people in a historical moment with the conditions of other people at the same historical moment and also with the conditions actualized by humanity in terms of the knowledge of the value of certain human potentialities. "This is the knowledge of what a human being can become, of the significance, for humanity, and of the achievements of those who have actualized such potentialities. Made under the light of this knowledge, such a comparison affords us an hypothetical or conditional knowledge: the knowledge of one or some conditions, in which it is normally impossible for a human being to actualize such human potentialities" (Kuçuradi 2007, 442).

Thus, Kuçuradi shows the ground on which the demand for justice is established by her latter comparison. Therefore, she indicates the ground forming the condition of injustice. Then, from the injustice which reveals a human condition and appears in various forms, she defines justice as follows.

Thus justice appears to be a meta-principle: the demand that the norms determining the arrangement of social relations and political action be deduced, at every historical moment, considering the existing conditions in the light of the knowledge of human rights... thus justice appears to demand the permanent creation of different, changing and favourable conditions, or not hindering the development of human beings and the human species, or in today's terminology, the protection of human rights in the different and changing conditions of any country and world. Human rights express the general conditions under which individuals—we think-could and might actualize their human potentialities, i.e., as human beings, may get as well as the ò $\quad \varepsilon \imath \lambda$ ó $\mu \varepsilon v \alpha$ to every human being. (Kuçuradi 2007, 444)

Here Kuçuradi notices that what the justice demands is not the effectiveness of some special, "material" principles.

According to Kuçuradi:

As the theories of justice usually think and try to put forth, but the will to fulfill permanently a chain of conditions leading to orders-varying and various orders but—of a special character: orders determined by historical-changing-norms and consequently laws, deduced at a given historical moment from the knowledge of the unchanging general pre-conditions of the actualization of human potentialities which make up what we call human dignity, i.e., from the knowledge of human rights... thus the concept of justice considered in its connection with human rights, appears to be a principle of volition-to use Kant's terminology, while human rights appear to be principles of action for the treatment of individuals, as well as principles for the deduction of law in general and of historical norms guiding the decisions taken in the arrangement of social relations and political action. (Kuçuradi 2007, 444)

In the light of all of these, it seems necessary to emphasize a few points by stressing them once again. Firstly, if we consider from the viewpoint of the actualisation degree of human potentialities which are reached at a certain moment by humanity as a species, we can see that Kuçuradi claims that this level forms the ground 
of her comparison carried out in the situation of injustice. Consequently, it can be stated that human potentialities which are the objects of the ground of comparison are not fixed as stable beings because of the feature of their ontological structure, but rather they are ontological structures which exist in the course of continuous becoming. Basing on this, Kuçuradi states that what is demanded by justice is not making effective material principles but a certain will with a formal structure, since human potentialities are formal structures due to the peculiarity of their ontological structure.

Secondly, Kuçuradi considers necessary the equal distribution of the products of the human achievements between people and groups in order to get over the situation of injustice. These products are brought about by the actualisation of human potentialities that are based on the structural property of humans. In the background of this necessity, an assumption takes place that these products are the common heritage of humanity. Kuçuradi gives the invention of electricity by Edison as an example of human achievements. At first glance, the invention of it seems to be the achievement of only one person, but without achievements of other people which also depend on the achievements of other persons, it is not possible. Thus, when we look at the background of the achievement of one person, it is seen that it has ground extending gradually towards the achievements of more and more human beings from different periods, regions, and identities.

As the third and last point, according to Kuçuradi, the feature of the ontological structure of the human potentialities which are not distributed equally between the people and groups in the situation of injustice, makes it possible to conceptualize the idea of justice (Kuçuradi 1994, 32) which is the necessary condition for overcoming the situation of injustice, in other words to reply the question of "What is justice?" with an answer that can be cognitively justifiable. This formal peculiarity of ontological structure, according to Kuçuradi, makes it possible to form a law to overcome the situation of injustice.

\section{Kant's Concept of Respect}

However, at this point, it may be said that the situations of injustice can be surpassed by the feeling of respect for human beings in the Kantian sense before conceptualizing the idea of justice as a precondition. In this Kantian sense, the respect for human beings is above all a feeling. However, for Kant, it is not a passionate feeling like others which are based on inclinations such as selfishness and self-conceit and which appear at a certain stage where the moral law has not yet determined the will. A feeling of respect is an a priori feeling which appears after the determination of will by the moral law. Hence, according to Kant, the object of respect is the Law only (Kant 1900, 18). Moral law commands human beings to will in such a manner that when he or she acts in relation to himself and to others, human beings should be considered not as a means but as an end. In other words, the object of the Kantian feeling of respect is a will which is aware of that human being is a valuable being. Only such kind of will, a will determined by the moral law can be the object of respect.

According to Kant, since respect is a feeling directed only to the moral law, and since the subject of the moral law is a human being, it is directed merely to people and never to things. Respect is respect for human beings. Since it is an a priori feeling which finds its base in pure reason, respect is always immanent. However, passionate feelings are transcendent because they are a posteriori, so they are always directed toward things. If a person is aware of honesty in another person, then with an urge he or she can not but feel respect for that person even though he or she is the most ordinary one. This is because everything that is good is always lacking in human beings and when he or she compares his or her action with that of himself or herself, he or she sees the law which destroys self-conceit and observes in the course of action that its proper action can be 
accomplished. Thus, according to Kant, "Respect for a person is properly only respect for the law (of honesty $\& c$.$) of which he gives us an example" (Kant 1900, 18).$

Hence, when we look at the situation of injustice determined by Kuçuradi on the basis of the feeling of respect in the Kantian sense, if those persons who have actualized their human potentialities at a higher state than other people in the same historical moment act in their actions with a will determined by the moral law, then a feeling of respect for human beings which is directed to them will appear inevitably in the persons who do not possess such potentialities. This shows that the appearance of the feeling of respect is a sine qua non for overcoming the situation of injustice. Only thereafter, by forming a law based on a valid answer to the question of "what is justice?" can one advance on the way to the solution to the problem.

The appearance of this feeling is required for overcoming the situation of injustice and it seems to be possible only through a moral education in the Kantian sense by which people who actualised human potentialities at higher level than others have a will determined by the moral law. According to the conception of this education in Kant, the purpose of moral education is to teach human beings the feeling of respect for his or her own value, in other words, to arouse the feeling of respect for the moral law which is found in man as a possibility or to give rise to the feeling of respect for human beings and to show them that human beings belong to the intelligible world which is beyond the world of sense. According to Kant, this is possible only if morality is presented as a purely moral motive which influences the human heart. This is because only as a result of this influence, the person bitterly condemns himself when, because of his inclinations, he did not realize the duties which he is certainly convinced that he must do and he is aware of the moral law in himself which is the law of intelligible world. Thus the more the morality is presented purely, the stronger its power is on the human heart. All interference of the motives originating from the happiness of the person is an obstacle against the influence of moral law on the human heart.

\section{Conclusion}

The main purpose of a moral education in the Kantian sense is an education directing people to act in accordance with the moral law, in other words, to a certain will through which the human being is seen not as a means but as an end. Therefore, one may also state that when it is seen from the other side, moral education in the Kantian sense is an activity for arousing the feeling of respect which is a basic human motive that exists as a potentiality in humanity as a species. This is a concept of education which should be understood in a similar sense to ethical education or human rights education and today they are expressed more frequently than before. From such a point of view, human rights education which is put on the agenda by Western, "developed" countries because of human rights violations taking place in "developing" or "undeveloped" countries and which is considered to be necessary for eliminating such violations, should be given first of all to the people of the "developed" countries who without hesitation express it on every occasion. However, it should be given especially to the politicians with the biggest share of these violations. Without such an education, the appearance of a will determined by the moral law becomes impossible. The possibility of such kind of will keeps alive the hope of the satisfaction of the demand for justice brought forth by the person living in the situation of injustice. This will should appear in the people who have actualized human potentialities at the highest level and it manifests itself as a consciousness which is aware of the notion that the actualisation of such potentialities is also a basic right for other people who have not actualized them yet. When it is absent and 
when a person has lost the hope of satisfying this demand, then the manifestation of the feeling of respect for humans which is the only feeling preventing terror incidents, becomes impossible.

\section{Works Cited}

Kant. Critique of Practical Reason and Other Works. Trans. Thomas Kingsmill Abbott. London: Longmans, Green and co., 1879. ---. Fundemental Principles of the Metaphysic of Morals. Trans. Margaret D. Huston. Dublin: The University Press, 1900.

Kuçuradi. Etik. Ankara: Türkiye Felsefe Kurumu Yayınları, 1999.

---. Adalet Kavramı [The Concept of Justice]. Ed. Adnan Güriz. Ankara: Türkiye Felsefe Kurumu Yayınları, 1994.

---. "Hukuk ve Etik." Bedia Akarsu Armağanı [A Gift for Bedia Akarsu]. Ed. B, Çötüksöken-D.Özlem. İstanbul: İnkılâp Kitabevi, 2000.

---. “Justice: Social and Global.” Philosophy Facing World Problems. Vol. 13. Ankara: Philosophical Society of Turkey, 2007. 